Jpn. J. Limnol., $60: 507-529,1999$

\title{
Quantum Yield of Photosynthesis and Spectral Absorption of Phytoplankton during the Stratified Periods at the Northern Basin of Lake Biwa
}

\author{
Yuji Tanaka, Ryohei Tsuda, Minako Mizutani and Osamu Mitamura
}

\begin{abstract}
To understand what factors govern the quantum yield for phytoplanktonic photosynthesis, field research was conducted in the northern basin of Lake Biwa in September of 1994 and 1995, when the water column was still thermally stratified. Vertical distributions of underwater spectral light energy, its absorption by phytoplankton, as well as photosynthesis and primary productivity were observed, together with temperature, chlorophyll $a$ fluorescence, beam transmittance, and nutrient concentrations. The optical absorption coefficient, averaged over the wavelengths of photosynthesically active radiation (PAR), co-varied with sum of chlorophyll $a$ and phaeopigment concentrations as has been reported in previous studies. The quantum yield of phytoplanktonic photosynthesis, $\phi$, increased exponentially with decreasing radiation. This was clear in the high radiation region where scalar PAR exceeded $10 \mathrm{E} \mathrm{m}^{-2}$ day $^{-1}$. Also, $\phi$ increased with decreasing specific absorption by phytoplankton, and especially with increasing dissolved inorganic nitrogen concentration under weak light. These results suggest that phytoplankton could efficiently utilize the absorbed light energy for photosynthesis under weak radiation in deep water.
\end{abstract}

Key words : quantum yield, primary production, spectral absorption, Lake Biwa

\section{INTRODUCTION}

Since phytoplankton assimilate a significant amount of carbon from the atmosphere into the hydrosphere (e.g., WHITTAKER and LIKENS, 1973), the need to establish a means to quantify the phytoplanktonic primary production cannot be stressed enough, so that the missing fraction of global carbon fixation (TANs et al., 1990) can be explained. Although various studies have been made to estimate global abundance and primary production of phytoplankton, there is still room for improvements in methods and theory (cf., ROESLER et al., 1989 ; GaRVER et al., 1994). GORDON et al. (1983) first established a technique to estimate the phytoplankton abundance based on pigment concentrations in the pelagic ocean surface using remote sensing from satellite, which can observe a fairly wide area on the earth at a single 
time. Primary productivity can be estimated from measurements of the physiological properties of phytoplankton such as spectral light absorption and quantum yield of photosynthesis (KIEFER and MitchelL, 1983 ; BIDIGARE et al., 1987 ; CleVELAND et al., 1989). This technique relies on a bio-optical model providing a convenient means to estimate the phytoplanktonic primary productivity, so that no culture of phytoplankton is needed (ROESLER et al., 1989).

Considering such bio-optical techniques, it is important not to neglect the changes in the spectral distribution of radiant energy of sunlight with depth in the water column, because the attenuation of light is dependent on its wavelength. This is important since the process of phytoplankton photosynthesis depends on the efficiency of the spectral distribution of light absorption (e.g., KIRK, 1983). Such depth variations in the light environment accordingly affect the quantum yield of photosynthesis by phytoplankton. For example, in the northern basin of Lake Biwa, the spectral distribution of underwater light intensity peaks around $550 \mathrm{~nm}$. This feature becomes clearer with depth (TsudA, 1980 ; TsudA and NAKANISHI, 1989; 1990), because of the attenuation of certain wavelengths of light passing through the water column.

In lakes, underwater processes governing such productivity should not differ from those in the oceans, but have not been exploited so far. In fact, detailed measurements can be made more easily in lakes and thus more often than in the open ocean. In this context, such experiments in lakes would be advantageous since they would give insight to our understandings for the marine systems that require some fine measurements of bio-optical processes. We thus made a series of field measurements in the northern basin of Lake Biwa in September of 1994 and 1995, when the water column was thermally stratified, to explore the factors that govern the quantum yield of phytoplankton photosynthesis. The purpose was to simplify the bio-optical method to estimate primary production by examining the vertical effects of the spectral distributions of both light energy and its absorption by phytoplankton on primary productivity. Thus, the nature of the quantum yield of phytoplankton photosynthesis, i.e., the actual status and the possible cause of its spatial variations will be elucidated.

\section{MATERIALS AND METHODS}

\section{Field observations}

Observations were made in the northern basin of Lake Biwa at Sta. A $\left(35^{\circ}\right.$ $10.36^{\prime} \mathrm{N}, 135^{\circ} 58.01^{\prime} \mathrm{E}$ ), with a water depth of $50 \mathrm{~m}$ (Fig. 1). Measurements were repeated on 12, 14 and 16 September 1994 and 4, 5 and 6 September 1995.

The photosynthesically active radiation incident at the surface (PAR), which is an integrated value between $400-700 \mathrm{~nm}$, was continuously recorded using a Biospherical quantum scalar reference sensor (QSR-240) situated on the shore at Wani-town near Sta. A. This measurement will be referred 


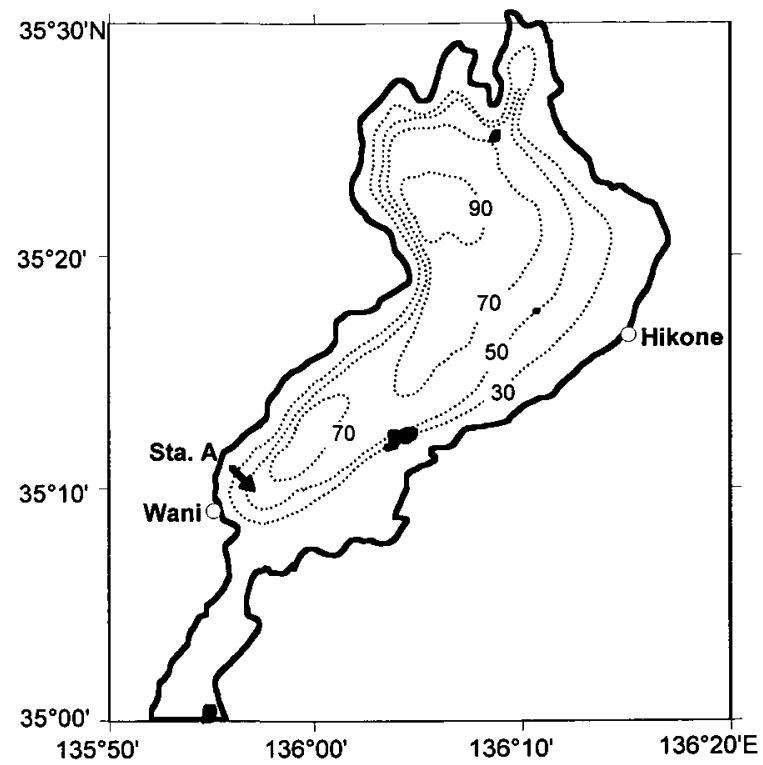

Fig. 1. Map showing the study site. The underwater environment was observed at Sta. A. PAR sq was recorded on the shore at the town of Wani. Meteorological data were measured at the Hikone Observatory.

to as the scalar PAR $\left(\mathrm{PAR}_{\mathrm{sq}}\right)$. At the same time, the underwater light environment was sampled using a Biospherical underwater radiometer (MER-1032), which measures the downward irradiance $E_{d}(\lambda)$ at fixed wavelengths of $410,441,475,488,507,540,565,589,610,640,660,675$ and $690 \mathrm{~nm}$, and upward irradiance $E_{u}(\lambda)$ and radiance $L_{u}(\lambda)$ at 410,441 , $465,488,520,565,625,671$ and $700 \mathrm{~nm}$. These measurements as well as pressure were recorded every $145 \mathrm{msec}$ during the $1 \mathrm{~m} \mathrm{sec}^{-1}$ downcast to a depth of $30 \mathrm{~m}$ which is deeper than the euphotic layer. Secchi depth was also measured. These downcasts were made very carefully to ensure that the shadow of the research boat did not interfere with the optical measurement.

Simultaneously with the radiometry, vertical profiles of temperature, chlorophyll $a$ fluorescence (FL), and turbidity at $660 \mathrm{~nm}$ were obtained from the surface to a depth of $30 \mathrm{~m}$, using a Sea Bird CTD (conductivitytemperature-depth) sensor (SBE-25), with a Sea Tech fluorometer for FL, and a Sea Tech transmissometer with $25 \mathrm{~cm}$ path length. The FL values were calibrated against chlorophyll $a\left(\mu \mathrm{g} 1^{-1}\right)$ measured spectrophotometrically in discrete water samples as described below. Measurements of meteorological data, including air temperature, solar radiation, precipitation, and wind force and direction were recorded at the Hikone Observatory (Fig. 1).

Depth-discrete water samples for analysis of algal composition, pigment and nutrient concentrations were collected in pre-cleaned 6-litre Van Dorn plastic bottles, and subsamples were filtered through $450^{\circ} \mathrm{C}$ pre-combusted Whatmann $\mathrm{GF} / \mathrm{C}(47 \mathrm{~mm})$ glass fiber filters using a vacuum pressure of 
approximately $200 \mathrm{~mm} \mathrm{Hg}$. The filters were sucked dry and stored at $-20^{\circ} \mathrm{C}$ until pigment analysis (vide infra).

Water samples for measurements of primary productivity and chlorophyll $a$ (Chl- $a$ ) pigment concentrations were obtained using pre-cleaned 10-litre Van-Dorn sample bottles at depths where PAR values were 100, 50, 25, 10, 5,1 and $<1 \%$ of the PAR at the air/water interface. Sampling depths are as shown in Table 1 . The sample water was also used for measurements of primary productivity according to STEEMANN NIELSEN (1952) by inoculating water samples with ${ }^{14} \mathrm{C}$-labeled bicarbonate and incubating in situ from noon to sunset. Carbon dioxide concentrations in these water samples were determined according to SATAKE et al. (1972).

Table 1. Depth of water bottle sampling on each day of observation.

\begin{aligned} & \hline \multicolumn{1}{c}{ Date } Depths of sampling (m) \\ & \hline 12 Sep. '94 $0,4,8,13,15,18,25 \\ &$ 14 Sep. '94 $0,1,2.5,5,8,15,16,18,25 \\ &$ 16 Sep. '94 $0,1,2,5,10,15,19 \\ &$ 4 Sep. '95 $0,1,2,4,6,9,15,25 \\ &$ 5 Sep. '95 $0,1,2,4,6,9,15,25 \\ &$ 6 Sep. '95 $0,1,2,4,6,9,15,25 \\ &$\hline\end{aligned}

\section{Analysis}

The composition of phytoplankton was determined microscopically using water samples fixed with Lugols solution. Samples for autotrophic picoplankton (APP) enumeration were separately fixed with $1 \%$ gluteraldehyde solution and then filtered on $0.2 \mu \mathrm{m}$ Nuclepore filters. Excitation by green light was used to enumerate the APP on the filter using an epi-fluorescence microscope.

Later, pigments were extracted from the particles on the filter using a $90 \%$ solution of acetone in water. The concentrations for the chlorophyll $a$ pigment (Chl-a) and phaeopigment (Phaeo) were measured according to LORENZEN (1967). Measurements of dissolved inorganic phosphorus (DIP), and total dissolved nitrogen (ammonium, nitrite and nitrate, (DIN)) were made according to the methods described in MURPHY and RILEY (1962), SAGI (1966), BendschneIDER and RoBinson (1952), and Wood et al. (1967).

To measure the spectral absorption by phytoplankton, water samples were filtered through Whatmann GF/F filters $(47 \mathrm{~mm}$ ). Then, using a Shimadzu spectrophotometer (MPS-2000), analysis was made according to the following procedures: (a) the optical density of all suspended particles of the original sample water was evaluated applying the opal glass transmission method (ShIBATA, 1958 ; Kishino et al., 1985) ; this is expressed as $O D_{p}$ $(\lambda)$, which is dependent on wavelength $\lambda$; (b) thereafter, photosynthetic 
pigments on the filter were removed by extraction in $99.5 \%$ ethanol for 90 min, and the optical density of suspended particles other than phytoplankton was measured, $O D_{d}(\lambda) ;(\mathrm{c})$ the measurements of the $O D_{p}(\lambda)$ and $O D_{d}(\lambda)$ were used to calculate spectral absorption coefficients due to all kinds of suspended particles $a_{p}(\lambda)$ and detritus $a_{d}(\lambda)$, according to KISHINo et al. (1985). Thus :

$$
\begin{aligned}
& a_{p}(\lambda)=\frac{2.3 \times O D_{p}(\lambda)}{\beta_{p}(\lambda) \times \frac{V}{S}} \\
& a_{d}(\lambda)=\frac{2.3 \times O D_{d}(\lambda)}{\beta_{d}(\lambda) \times \frac{V}{S}}
\end{aligned}
$$

where $V$ is the filtered volume of sample water, $S$ is the area of the filter. In order to compensate for the increase in the path length due to the use of glass fiber filters (KIEFER and SoOHOO, 1982) on $a_{p}$ and $a_{d}$, correction factors $\beta_{p}$ and $\beta_{d}$, must be applied, these are expressed as :

$$
\begin{aligned}
& \beta_{p}(\lambda)=1.63 \times O D_{p}(\lambda)^{-0.22} \\
& \beta_{d}(\lambda)=1.63 \times O D_{d}(\lambda)^{-0.22}
\end{aligned}
$$

(Mitchell and Kiefer, 1988a ; Bricaud and Stramski, 1990).

Then, according to KisHiNo et al. (1985), the spectral absorption coefficient due to phytoplankton $a_{p h}(\lambda)$ was calculated as :

$$
a_{p h}(\lambda)=a_{p}(\lambda)-a_{d}(\lambda)
$$

The values of $a_{p h}(\lambda)$ are subject to variation in accordance with the size distribution of phytoplankton, pigment concentrations, and pigment species (MOREL and BRICAUD, 1981). Because chlorophyll $a$ pigment eventually utilizes all the radiation energy absorbed by any other auxiliary pigment, it is necessary to compare the efficiency of absorption between different samples, $a_{p h}(\lambda)$ by dividing the sum of Chl- $a$ and Phaeo to derive the specific absorption coefficient $a_{p h}^{*}(\lambda)$.

To measure the spectral absorption by dissolved materials (yellow substances), water samples were filtered through $0.2 \mu \mathrm{m}$ Nuclepore filters soon after sampling and stored at $-85^{\circ} \mathrm{C}$ until the later analysis of spectral absorption. The deep-frozen specimens were allowed to melt at $20^{\circ} \mathrm{C}$ and then the optical density of yellow substances $O D_{y}(\lambda)$ was measured using a $10 \mathrm{~cm}$ quartz cell (BriCAUD et al., 1981). The spectral absorption coefficient due to yellow substances $a_{y}(\lambda)$ is given by:

$$
a_{y}(\lambda)=\frac{2.3 \times O D_{y}(\lambda)}{d}
$$

When $d=0.1$, is the path length in meters of the quartz cell. The spectral absorption coefficient of the water molecules $a_{w}(\lambda)$ was calculated according to SMITH and BAKER (1981).

Using these spectral absorption measurements, the ratios of absorption at wavelengths of $565 \mathrm{~nm}$ (mainly by phycoerythrin) and $675 \mathrm{~nm}$ (representa- 
tive of the Chl- $a$ absorption), $a_{p h}(565) / a_{p h}(675)$, were calculated to show the relative contributions to energy absorbance of phycoerythrin to Chl- $a$.

In addition to the spectral absorption measurements, the quantum yield of photosynthesis, $\phi\left(\operatorname{mol~C~E} \mathrm{E}^{-1}\right)$, was calculated according to the method described by MOREL (1978) and Kishino et al. (1986). $\phi$ is a measure of the amount of organic material produced per unit of radiant energy absorbed by phytoplankton. $\phi$ reflects the photosynthetic activity of phytoplankton and is expressed as :

$$
\begin{aligned}
\phi & =\frac{P^{\prime}}{\mathrm{PUR}} \\
& =\frac{P^{\prime}}{E_{s c}(\mathrm{PAR}) \times \overline{a_{p h}^{*}}(\mathrm{PAR})}
\end{aligned}
$$

given that,

$$
\overline{a_{p h}^{*}}(\mathrm{PAR})=\frac{\int_{400}^{700} a_{p h}^{*}(\lambda) \times E_{d}(\lambda) d \lambda}{E_{d}(\mathrm{PAR})}
$$

and where $P^{\prime}$ is the Chl- $a$-specific rate of primary production, and PUR is the photosynthetically usable radiation, the actual energy absorbed by phytoplankton. $E_{s c}(\mathrm{PAR})$ is a product of the surface quantum scalar irradiance $\left(\mathrm{PAR}_{\mathrm{sq}}\right)$ and the ratio of the PAR at each sampling depth to that at the water surface, and $a_{p h}^{*}(\mathrm{PAR})$ is the Chl- $a$ specific absorption coefficient summed over the PAR active wavelengths. $E_{d}(\mathrm{PAR})$ is obtained from the area of the curve under the $E_{d}$ vs. $\lambda$ measurements at each sampling depth. In each of the above equations, PAR refers to the integrated value over the PAR band $(400-700 \mathrm{~nm})$.

Correlation between two variables were tested after SNEDECoR and COCHRAN (1967).

\section{RESULTS}

\section{Meteorological background}

In 1994 air temperature and solar radiation regularly showed typical diurnal fluctuations from 12-15 September while the weather was fine (Fig. 2 ). Typically for the research area, the wind blew weakly from the southeast before noon and changed to blow from the northwest in the afternoon. On 16 September, the passage of a cloudy weather front significantly reduced the solar radiation and resulted in $50 \mathrm{~mm}$ of precipitation. In 1995 the weather during the period of field observations was stable, showing regular diurnal fluctuations. Solar radiation was slightly higher than during the 1994 period of observation. From the afternoon of 4 September through 5 September, winds blowing from the northwest, sometimes exceeding $4 \mathrm{~m}$ $\mathrm{sec}^{-1}$ dominated, but on 6 September again showed the typical diurnal rhythm, with weak velocities.

The values of scalar $\mathrm{PAR}_{\mathrm{sq}}$ during 1994 sampling period reflected bad weather on the afternoon of 12 September, followed by clear days on the 

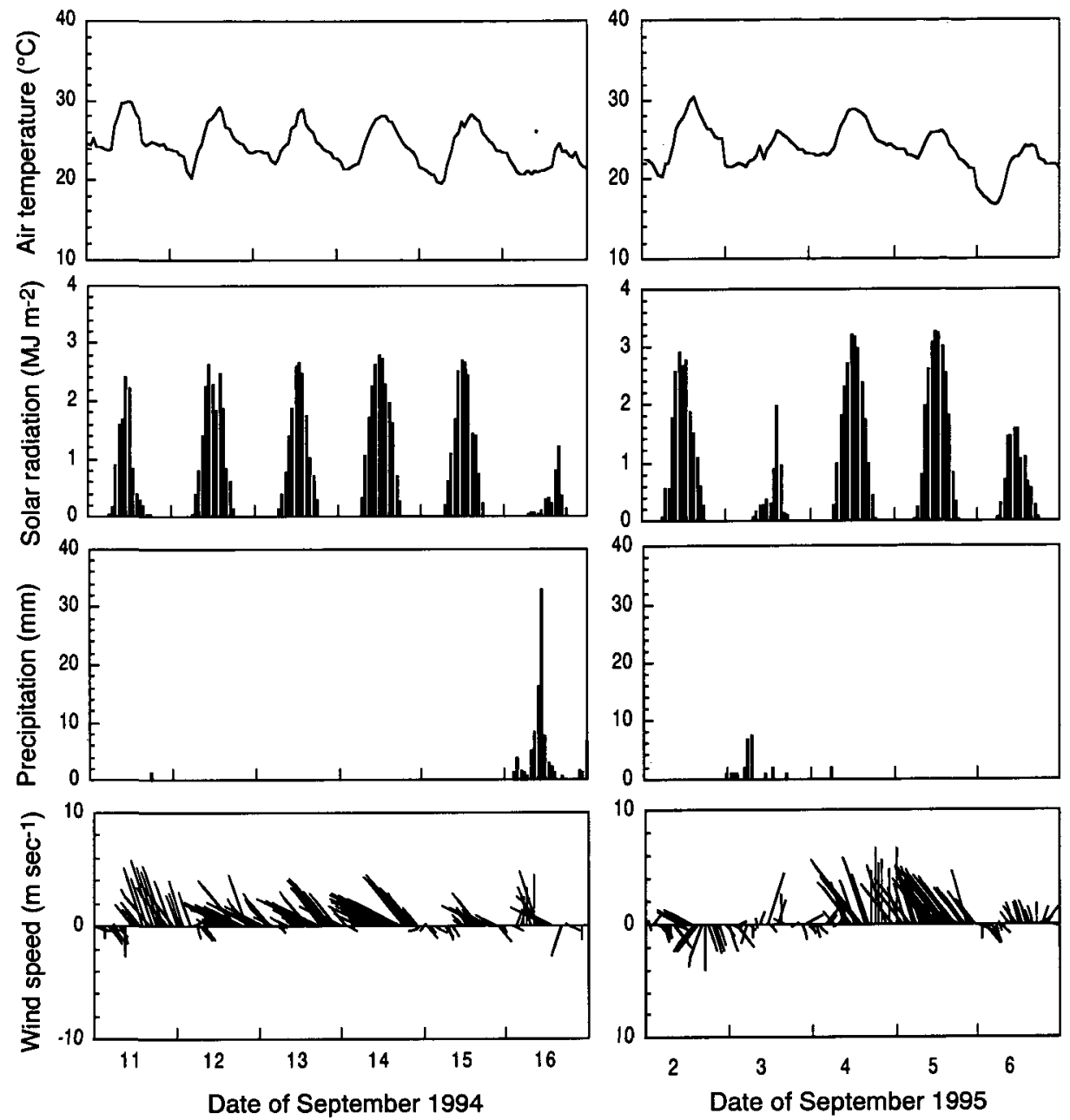

Fig. 2. Hourly record of air temperature, solar radiation, precipitation and wind vectors in 1994 and 1995. Wind sticks indicate the direction from where the wind blew (up : N, down : S).

14th and 15th, and the passage of a weather front on 16th (Fig. 3). In 1995, on 4 and 5 September there were basically high values of $\mathrm{PAR}_{\mathrm{sq}}$, the noise related to passing of clouds, followed by a relatively low $\mathrm{PAR}_{\mathrm{sq}}$ of 6 September due to the presence of thick clouds (Fig. 3).

\section{Water temperature, chlorophyll $a$ fluorescence and beam transmi- ttance}

On 12 September 1994 (Fig. 4), the epilimnion consisted of vertically homogenized water at $27^{\circ} \mathrm{C}$ showing a sharp thermocline at $14 \mathrm{~m}$ below the surface, related to the strong northwesterly that blew persistently from the afternoon of the 11 September. A similar structure was observed on 14 and 16 September, again influenced by a persistent northwesterly wind. The 


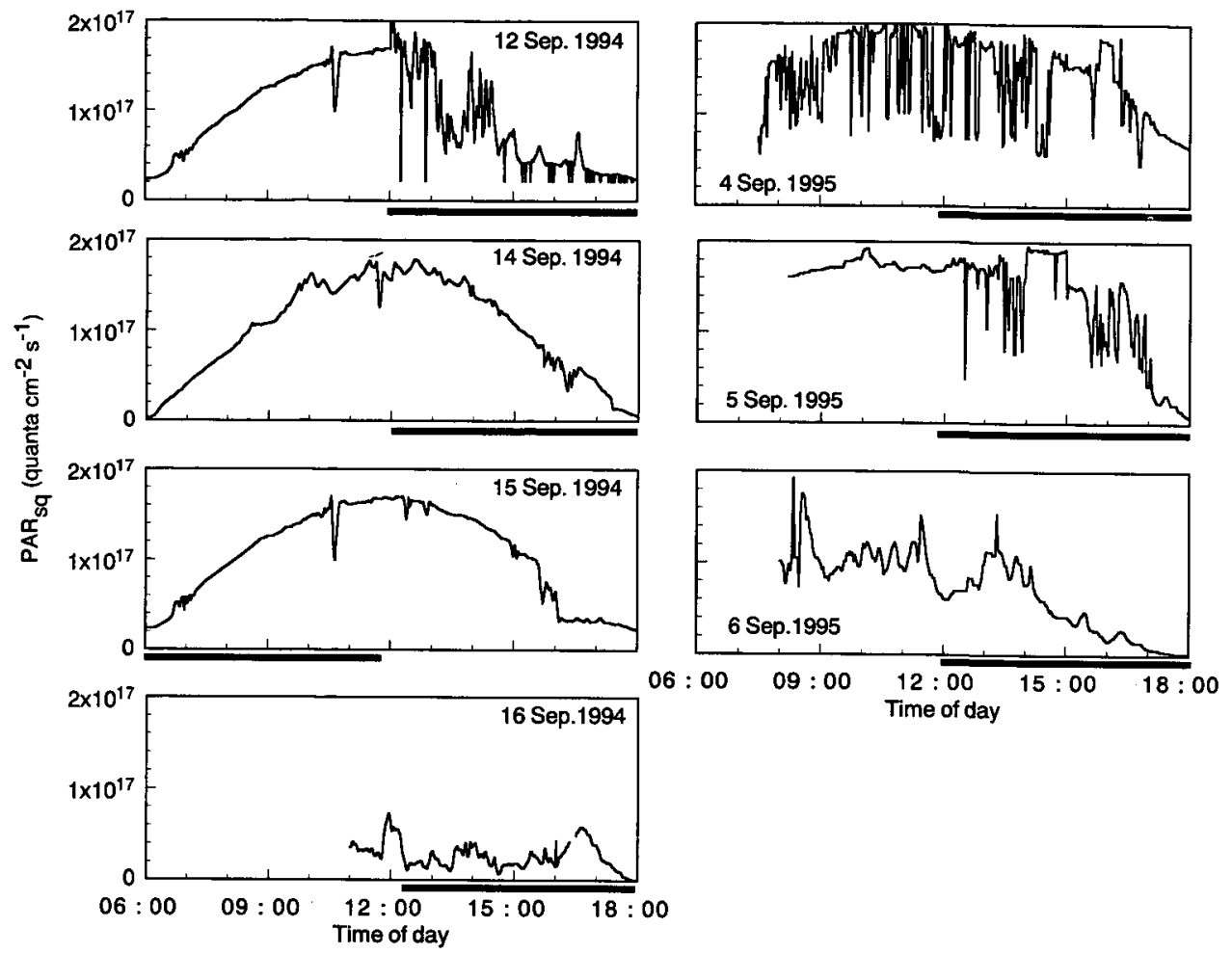

Fig. 3. Values of scalar PAR $\left(\mathrm{PAR}_{\mathrm{sq}}\right)$ recorded at Wani town. The horizontal bar below each $x$ axis denotes the period of time when the rate of primary production was measured in the lake.

thermocline, which was at about $14-15 \mathrm{~m}$ below the surface on 12 and 14 September, descended to $19 \mathrm{~m}$ on 16 September, perhaps reflecting an enhanced activity of internal waves resulting from the northwest winds. Chlorophyll $a$ fluorescence (FL) increased clearly downward from $<2 \mu \mathrm{g} \mathrm{l}^{-1}$ within the epilimnion to a maximum exceeding $8 \mu \mathrm{g} \mathrm{l}^{-1}$ at the base of the thermocline. Below the thermocline, FL rapidly decreased with increasing depth in the hypolimniion, becoming less than $2 \mu \mathrm{g} \mathrm{l^{-1 }}$ again at $30 \mathrm{~m}$ below the surface. Transmittance showed a marked minimum $(60 \%)$ in the metalimnion below the epilimnetic clear water of $80 \%$ transmittance, coincident with the Chl- $a$ maximum indicating that light attenuation in the thermocline was mainly due to the presence of a high concentration of phytoplankton.

In 1995, the thermocline was not as strongly developed as in 1994. It set in at around $10 \mathrm{~m}$ below the surface on 4 September, with the temperature decreasing from $25^{\circ} \mathrm{C}$ continuously to $10^{\circ} \mathrm{C}$ at the bottom. The FL maximum, with values about $2 \mu \mathrm{g} \mathrm{l}^{-1}$, was significantly smaller than that observed in 1994, but the peak was much broader and was within the epilimnion. By the next day, the temperature profile had changed dramatically, exhibiting the formation of a sharp thermocline below a deeper epilimnion at $15 \mathrm{~m}$ with 


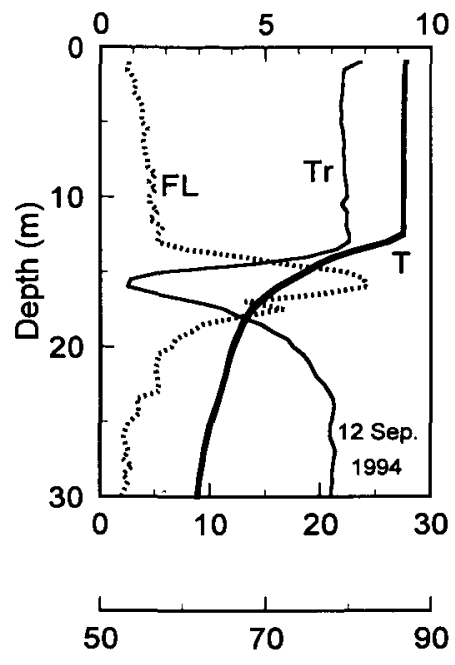

Chlorophyll a fluorescence $\left(\mu \mathrm{g} \ell^{-1}\right)$
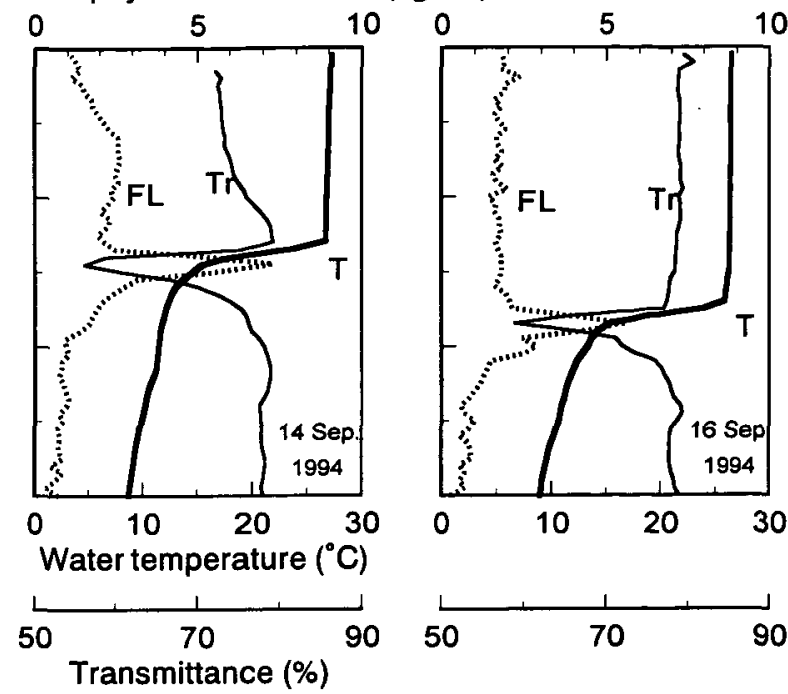

Chlorophyll a fluorescence $\left(\mu \mathrm{g} \ell^{-1}\right)$
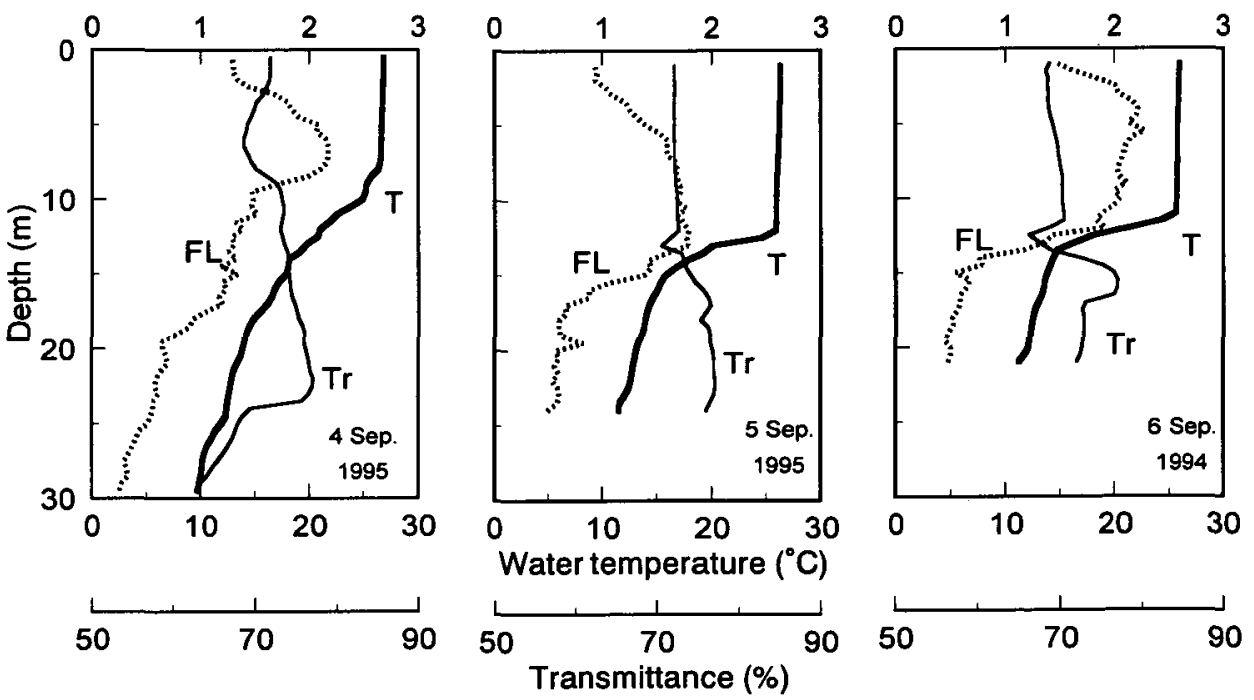

Fig. 4. Vertical profiles of water temperature (T), chlorophyll $a$ fluorescence (FL), and light transmittance $(\mathrm{Tr})$.

water $1^{\circ} \mathrm{C}$ colder than on the previous day. This may have resulted from the effects of a strong northwesterly wind which blew from the afternoon of 4 September through whole day of the 5 September. On 6 September, in comparison to the previous day, the FL vertical profile was similar in shape but there was clearly a greater amount of total chlorophyll $a$ in the epilimnion (Fig. 4). No metalimnetic maximum was seen, but FL exceeded $2 \mu \mathrm{g}$ $\mathrm{l}^{-1}$ broadly in the epilimnion; this suggests that some changes occurred in 
the environment for phytoplanktonic production between these two days, and also between 1994 and 1995.

$100 \times \operatorname{PAR}(z) /$ PAR $^{-} 0^{-}$
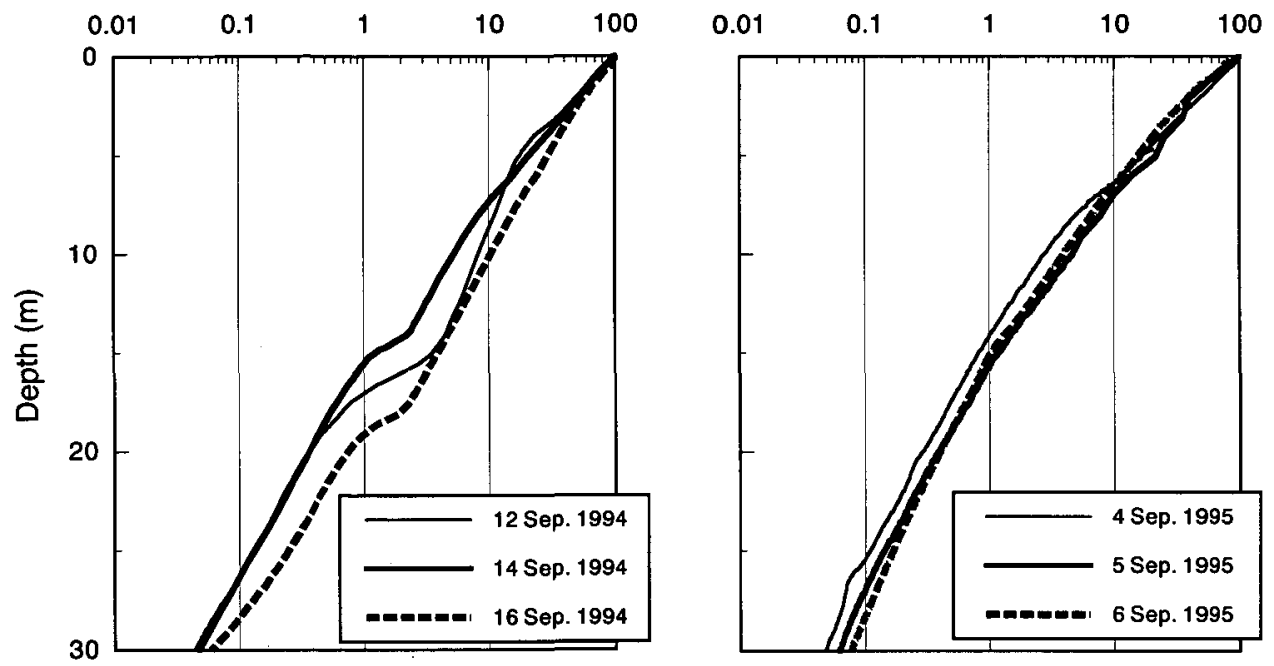

Fig. 5. Vertical profiles of underwater PAR observed in 1994 (left panel) and 1995 (right panel). The PAR values are expressed relative to the value observed immediately below the lake surface $\left(\mathrm{PAR} 0^{-}\right.$).
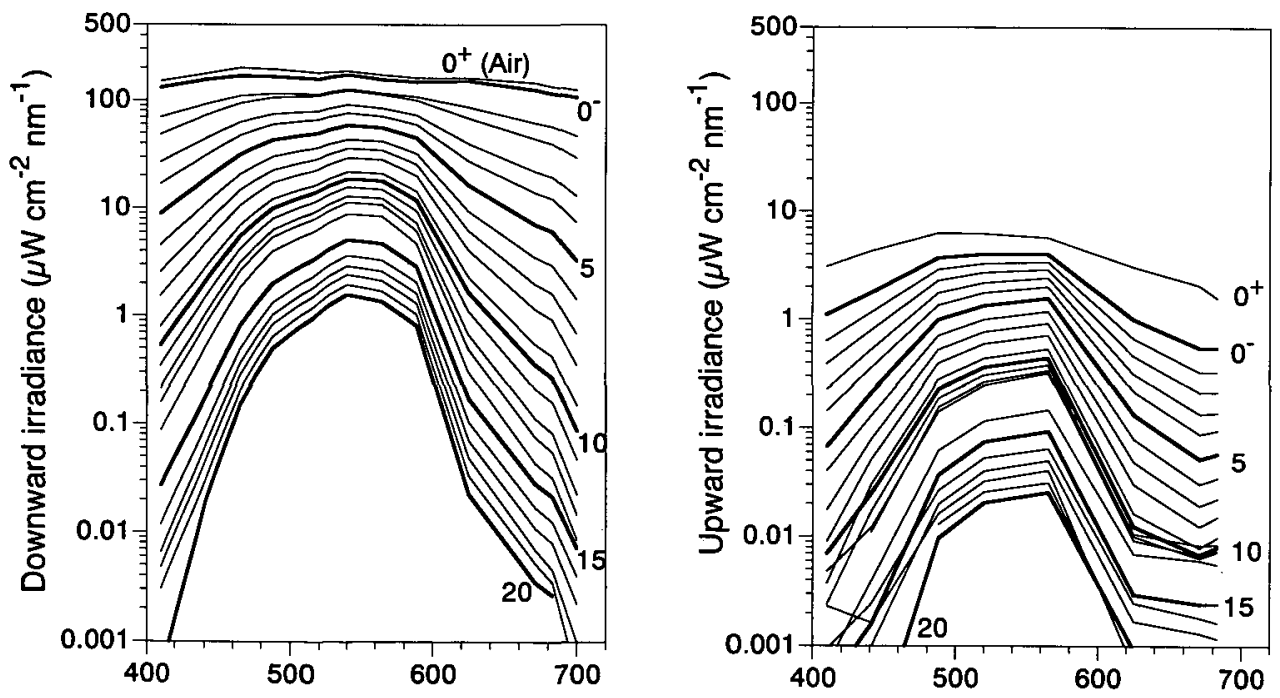

Wavelength $(\mathrm{nm})$

Fig. 6. Spectral distributions of downward and upward irradiance on 14 September 1994. Broken lines represent spectral irradiance at each meter of depth, as indicated by the numerals at the right. $0^{+}$and $0^{-}$denote immediately above and below the lake surface, respectively. 


\section{Optical environment}

Underwater light attenuation varied both temporally and vertically. The depths at which PAR was reduced to the $1 \%$ of its surface value, $Z_{1} \%$, was stable at $15 \mathrm{~m}$ below the surface in 1995 , but varied in 1994 (Fig. 5). $Z_{1} \%$ was found at about $16 \mathrm{~m}$ on 12 and 14 September 1994 and $19 \mathrm{~m}$ in 16 September 1994. In 1994, vertical profiles of PAR showed a layer with a steeper gradient coinciding with the FL maximum (Fig. 4). The reason $Z_{1 \%}$ on 16 September 1994 was deeper than on previous days may be due to a thickening of the epilimnion from internal wave action. Because of the dependence of light attenuation on wavelength, spectral irradiance deeper in the water peaked art $550 \mathrm{~nm}$ (Fig. 6) ; at a depth of $15 \mathrm{~m}$, about $75 \%$ of PAR came from the energy of green light $(500-590 \mathrm{~nm})$.

\section{Pigment concentrations and quantum yield of phytoplanktonic photo- synthesis}

In 1995, the Chl- $a$ plus Phaeo pigment concentrations were homogeneous in the epilimnion $\left(2-3 \mu \mathrm{g} \mathrm{l}^{-1}\right)$, but in the metalimnion were as low as $30 \%$ of those observed in 1994 (Fig. 7). There is no doubt, from the data shown
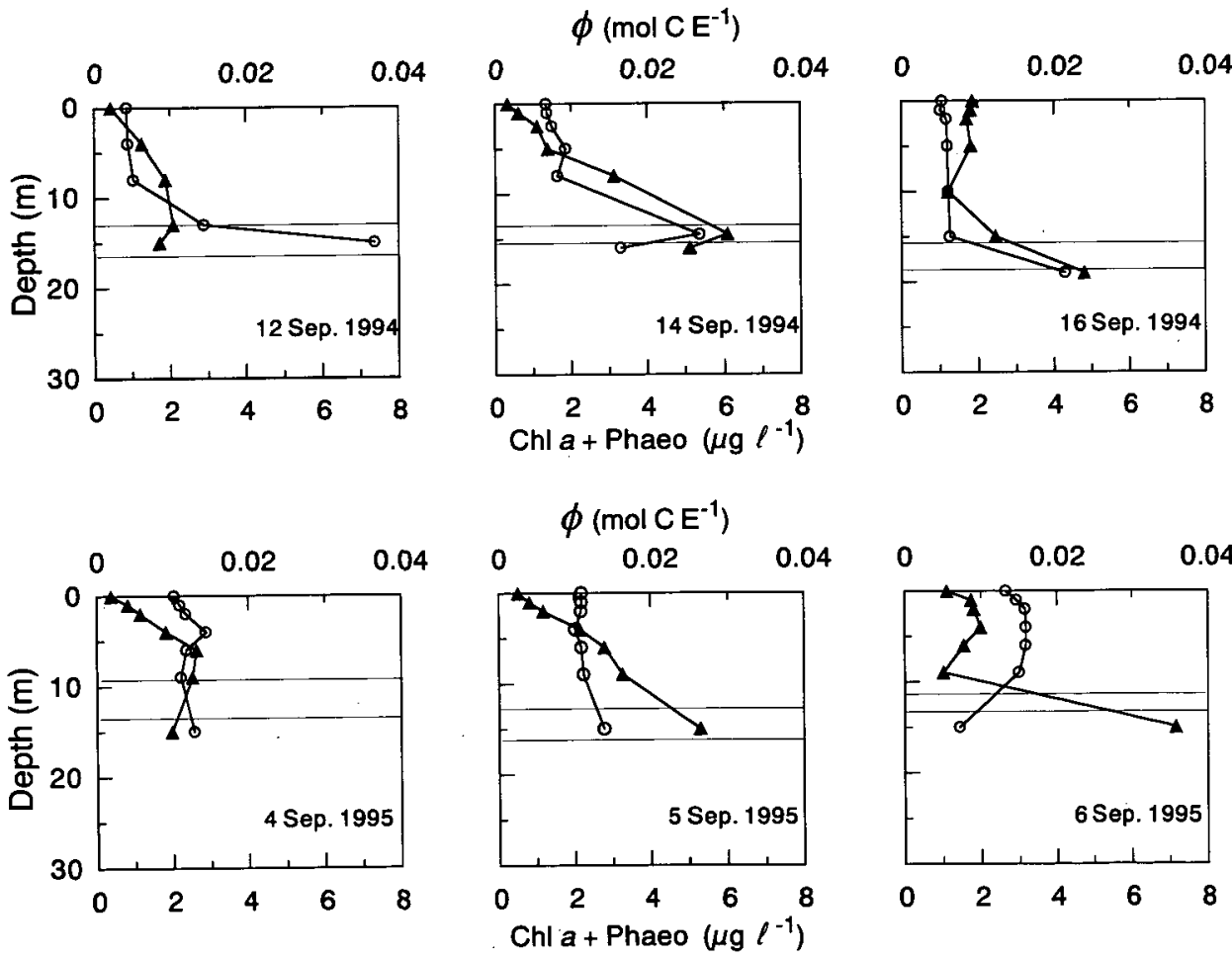

Fig. 7. Vertical distributions of quantum yield of photosynthesis $\phi(\Delta)$ and the concentrations of chlorophyll $a$ plus phaeo-pigments (Chl- $a+$ Phaeo; $\bigcirc$ ), for each day of observation in September 1994 (upper panel) and in 1995 (lower panel). The two bars on the $x$-axis of each graph indicate the upper and lower extent of the metalimnion. 

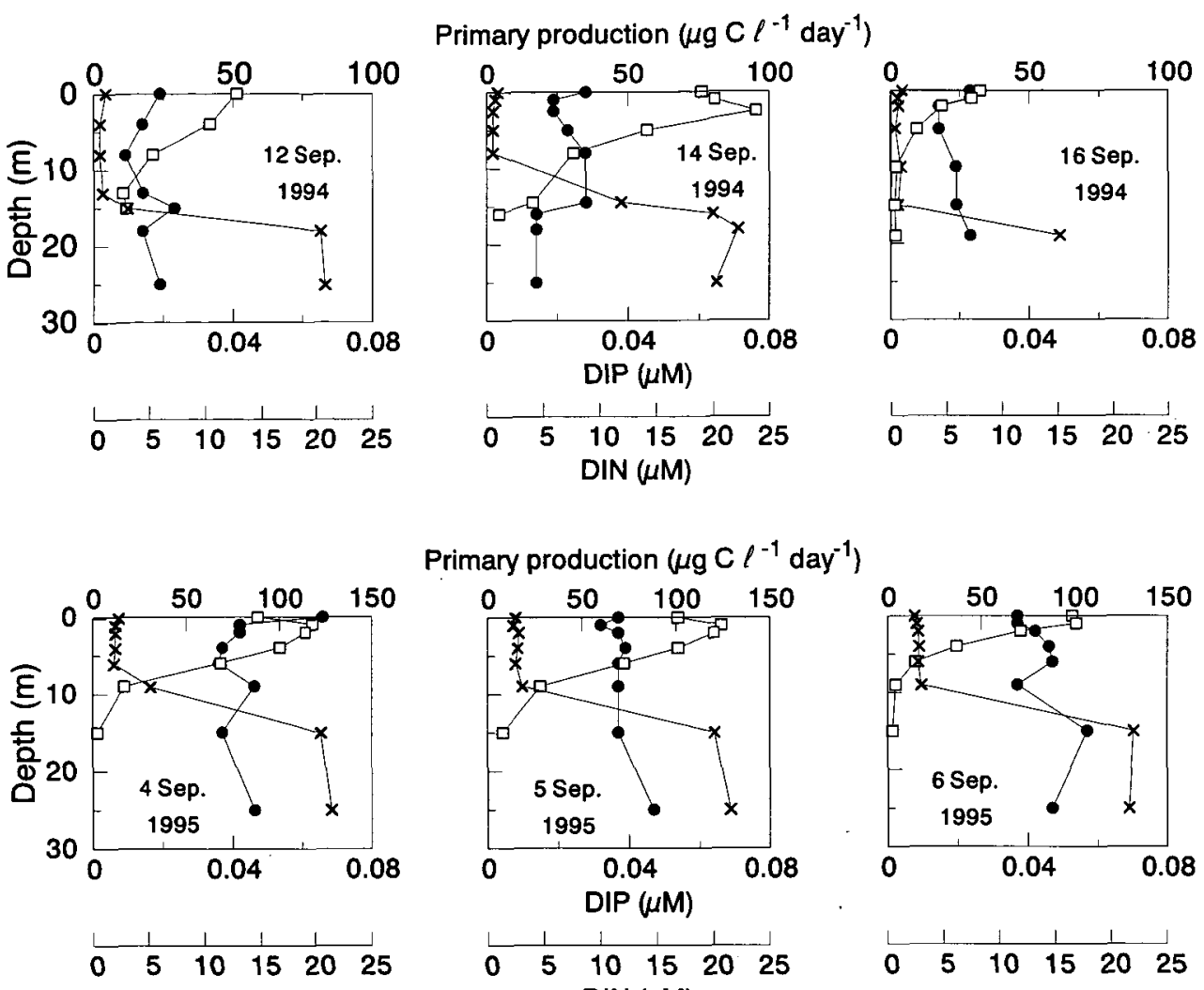

Primary production $\left(\mu \mathrm{g} C \ell^{-1} \mathrm{day}^{-1}\right)$
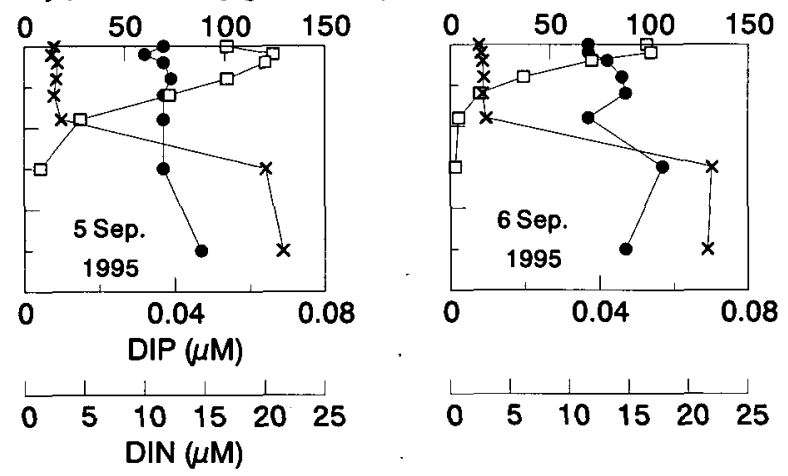

Fig. 8. Vertical distributions of daily primary production ( $\square$ ), dissolved inorganic nitrogen (DIN ; $\times$ ), and dissolved inorganic phosphorus (DIP; O) in 1994 (upper panels) and 1995 (lower panels).

in Figs. 4, 5, and 7, that the properties of the water column were very different during these two observational periods. These differences are also clear in the data for the rate of primary production and the concentrations of DIN and DIP (Fig. 8).

Measurements of $\phi$ ranged between 0.002 and $0.036 \mathrm{~mol} \mathrm{C} \mathrm{E}^{-1}$ (Fig. 7). Apparently when PAR $_{\text {sq }}$ was large, $\phi$ was small but showing an tendency of increase with decreasing $\operatorname{PAR}_{\mathrm{sq}}(p<0.01)$ (Fig. 9). Also, $\phi$ varied strongly. with the changes in $\overline{a_{p h}^{*}}(p<0.01)$ (Fig. 10), and covaried with the ratio of

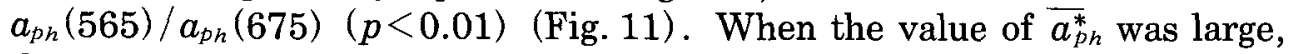
the value of $\phi$ was small.

\section{Phytoplankton species composition}

On the 12 and 14 September, autotrophic picoplankton (APP) such as Synechococcus sp. dominated at all depths (Fig. 12). Bacillariophyceae Aulacoseira granulata, Stephanodiscus carconensis and a Dinophyceae Ceratium hirundinella, at cell concentrations much smaller than those of APP were seen in epilimnion. APP was most abundant in the metalimnion. 


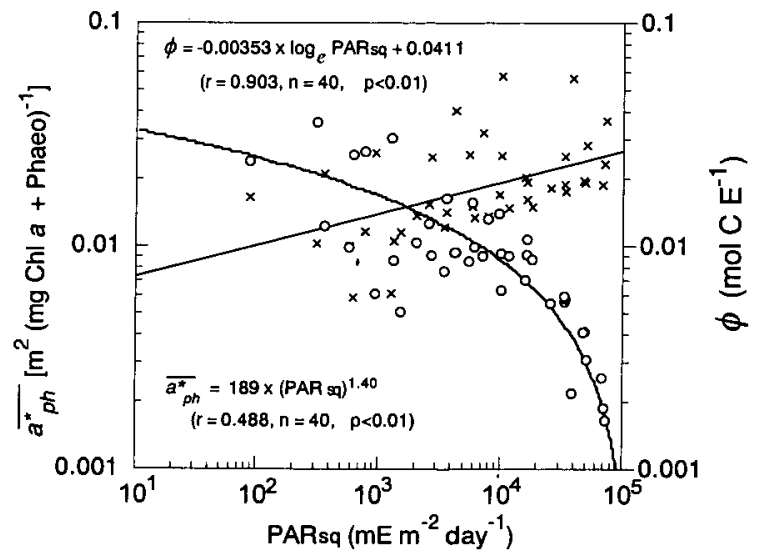

Fig. 9. The relationship between scalar photosynthesically active radiation PAR $_{\mathrm{sq}}$ (horizontal axis) and pigment specific coefficient of light absorption by phytoplankton $a_{p h}^{*}(\times)$, and quantum yield of photosynthesis $\phi(\bigcirc)$.

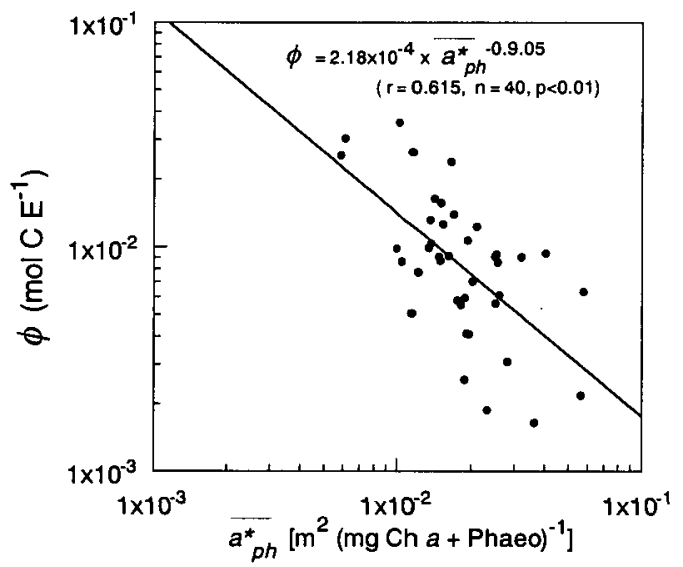

Fig. 10. Values in quantum yield of photosynthesis $\phi$ plotted with pigment specific absorption coefficient averaged over PAR, $\overline{a_{p h}^{*}}$.

In 1995, the same species of Bacillariophyceae, as seen in 1994, were present. The most dominant species on 4 September was $A$. granulata in the epilimnion, but in the hypolimnion $C$. hirundinella dominated. APP existed in the epilimnion, but was less concentrated in the metalimnion. On 5 September, the water was dominated at all depths by $C$. hirundinella and APP ; and in the metalimnion C. hirundinella predominated. The vertical distribution of the dominant species on 6 September was similar to that on 5 September, except for a little abundance of Chlorophyceae Scenedesmus spp.

\section{Light absorption by phytoplankton}

On 12 September 1994 , the values of $a_{p h}^{*}$ were as large as $0.12-0.15\left[\mathrm{~m}^{2}\right.$ 


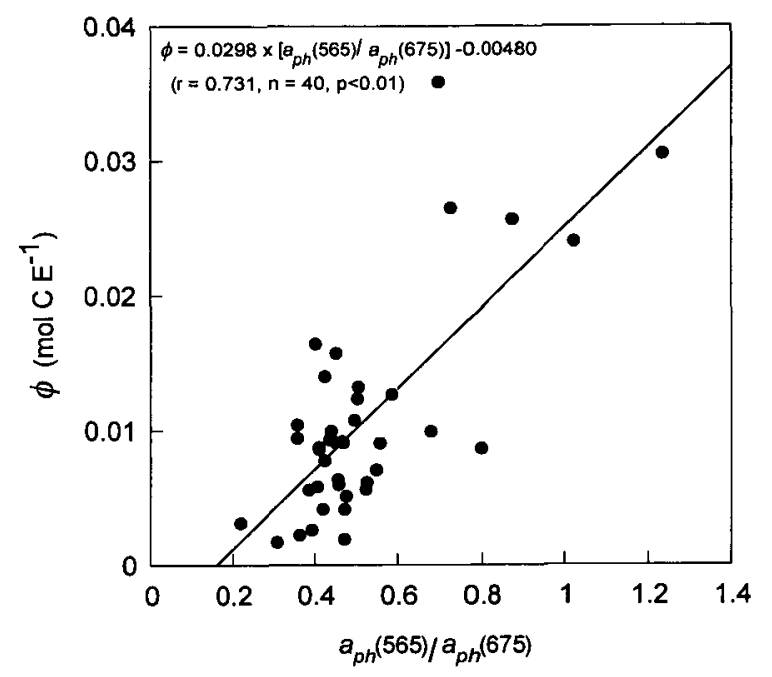

Fig. 11. The relation between the ratio of absorption coefficient at 565 and 675 $\mathrm{nm}, a_{p h}(565) / a_{p h}(675)$, and quantum yield of photosynthesis $\phi$.
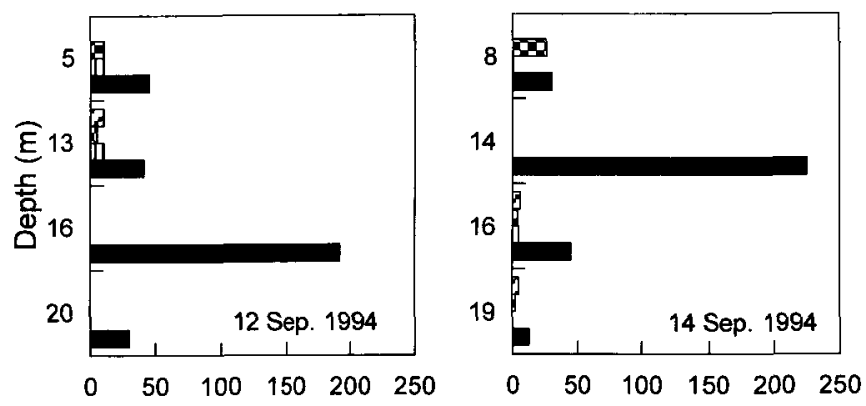

E: Aulacoseira granulata

D.: Stephanodiscus carconensis

س): Ceratium hirundinella

$\triangle:$ Scenedesmus spp.

- autotrophic picoplankton
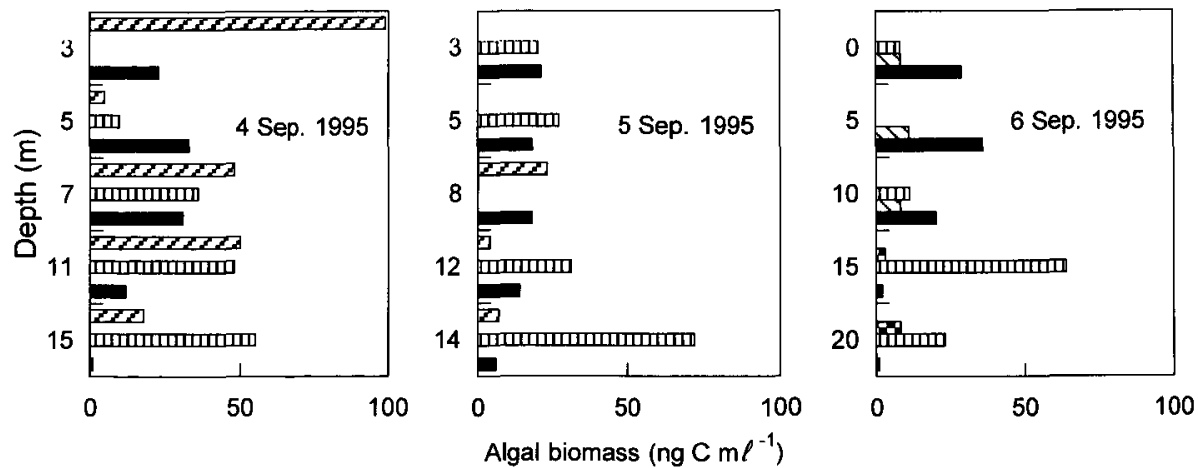

Fig. 12. The vertical distributions dominant species of algae.

(mg Chl- $a+$ Phaeo $\left.)^{-1}\right]$ measured at $440 \mathrm{~nm}$ in the epilimnion, showing a rapid decrease at depths below (Fig. 13). In addition to absorption by Chl- $a$ at $440 \mathrm{~nm}$, a small peak at $565 \mathrm{~nm}$ due to phycoerythrin was observed at each depth, especially in the metalimnion. This is in accord with the 
presence of Cyanophyceae at all depths as shown in Fig. 12. On comparing the data from 14 September with those from 12 September, the values of the epilimnetic $a_{p h}^{*}$ was smaller, although the concentration of Chl- $a$ was two fold greater. This is probably due to the packaging effect (MOREL and BRICAUD, 1981). On the 14th, water collected near the thermocline exhibited a higher absorption at $565 \mathrm{~nm}$ than on the 12th. On 16 September, no vertical variation was seen in the pattern of the absorption spectra, except that the water from a depth of $19 \mathrm{~m}$ (near the thermocline) showed a peak at $565 \mathrm{~nm}$.

In September 1995, values of $a_{p h}^{*}$ were generally smaller than those in 1994 (Fig. 13). There were no clear variations for the three days of observation. The spectra within the surface $9 \mathrm{~m}$ of water suggested absorption by carotenoids as well as by phycoerythrin at $450-500 \mathrm{~nm}$ (Fig. 13), because of the dominance of Bacillariophyceae and Cyanophyceae (Fig. 12). In water from a depth of $15 \mathrm{~m}$, while absorption by phycoerythrin was clear, these appeared to be little by carotenoids, this being similar to the pattern observed in 1994. In all of these observations, the epilimnetic values of the $a_{p h}(565) / a_{p h}(675)$ ratio were as low as $0.4-0.5$, until they increased in the metalimnion (Fig. 14). The increase was especially clear in September 1994, reflecting a higher concentration of phycoerythrin.

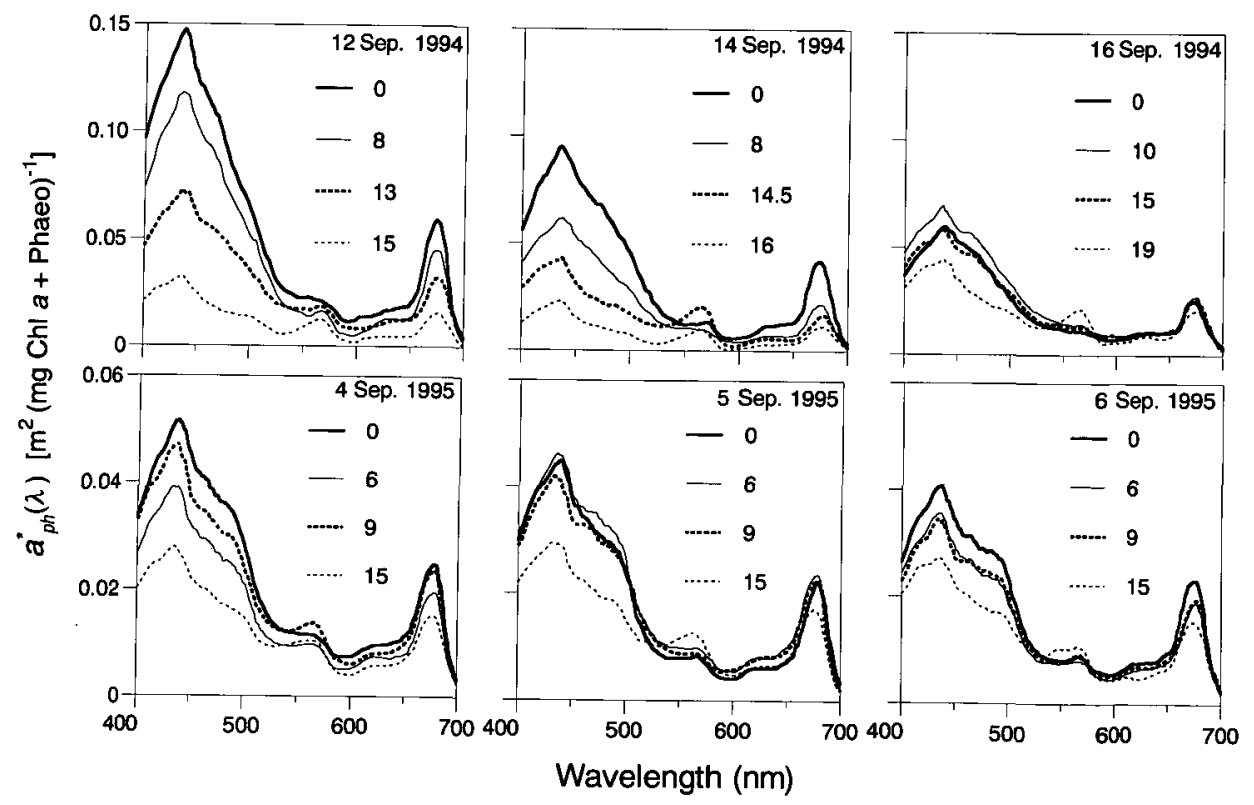

Fig. 13. Comparisons of the spectral distributions of phytoplankton pigment specific absorption $\left.a_{p h}^{*}\left[\mathrm{~m}^{2} \text { (mg Chl-a } a \text { Phaeo }\right)^{-1}\right]$ during the optical observations in September of 1994 (upper panels) and 1995 (lower panels). Numerals in chart indicates the sampling depth in meters. 

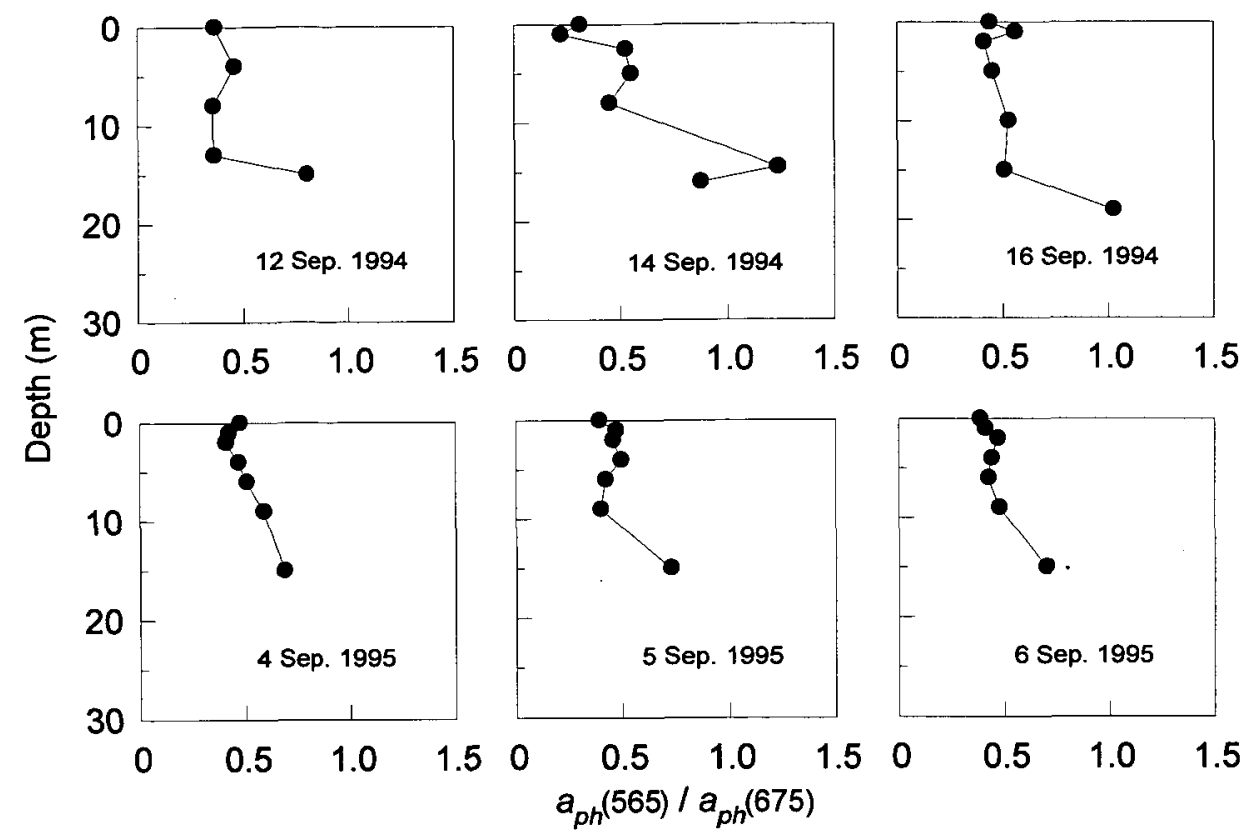

Fig. 14. The vertical change in the ratio of phytoplanktonic absorption coefficient at 565 and $675 \mathrm{~nm}, a_{p h}(565) / a_{p h}(675)$.

When the averaged values of absorption over the PAR band $\left(\bar{a}_{p h},\right)$ were plotted versus [Chl- $a+$ Phaeo], it was seen that $\bar{a}_{p h}$ increased with increasing [Chl- $a+$ Phaeo] $(p<0.01)$, (Fig. 15). On the contrary, for the pigment specific absorption $\bar{a}_{p h}^{*}$, there was a decreasing concentration with decreasing $\operatorname{PAR}_{\mathrm{sq}}(p<0.01)$, (Fig. 9), showing that the efficiency of light absorption by phytoplankton was decreasing with depth.

\section{Daily primary production and nutrients}

On 12 September 1994, the rate of daily primary production was highest at the surface, being as high as $50 \mu \mathrm{g} \mathrm{l}^{-1}$ day $^{-1}$, with a tendency to decrease with depth (Fig. 8). At a depth of $15 \mathrm{~m}$, it was only $20 \%$ of the surface value. On the 14th, the rate showed a maximum value of $90 \mu \mathrm{g} \mathrm{l}^{-1} \mathrm{day}^{-1}$ at $2.5 \mathrm{~m}$ from the surface, rapidly decreasing with depth to $10 \mu \mathrm{g} \mathrm{l}^{-1}$ day $^{-1}$ at $15 \mathrm{~m}$. On the 16th, due to weak solar radiation during the passage of weather front, the rate was lower than on the previous days. The maximum in the rate of primary production did not always coincide with the FL maximum in the thermocline (Fig. 4). The vertical profiles of DIN showed a rapid increase near the thermocline, while those of DIP varied little, with small values around $0.02 \mu \mathrm{M}$ (Fig. 8), which was about half of that of measurements in 1995 . This may be related to an unusually small amount of precipitation prior to the field survey of 1994 . In 1995, the daily rate of primary production for each day was highest at $1 \mathrm{~m}$ below the surface (Fig. 8 ), where PAR was $75 \%$ of the surface value (Fig. 6). It was higher than 
that in 1994 within the surface $5 \mathrm{~m}$, but at greater depths quickly decreased to show no difference from those seen in 1994.

Relations between DIN, $\mathrm{PAR}_{\mathrm{sq}}$ and $\phi$ (Fig. 16) showed that when DIN was $\leq 1 \mu \mathrm{M}, \phi$ increased with decreasing $\mathrm{PAR}_{\mathrm{sq}}$. Under weak light condition with higher DIN conditions, the value of $\phi$ reached a maximum, suggesting the dependence of $\phi$ on both DIN and PAR sq. While the DIN was low, $\phi$ seemed to depend on $\mathrm{PAR}_{\mathrm{sq}}$ only.

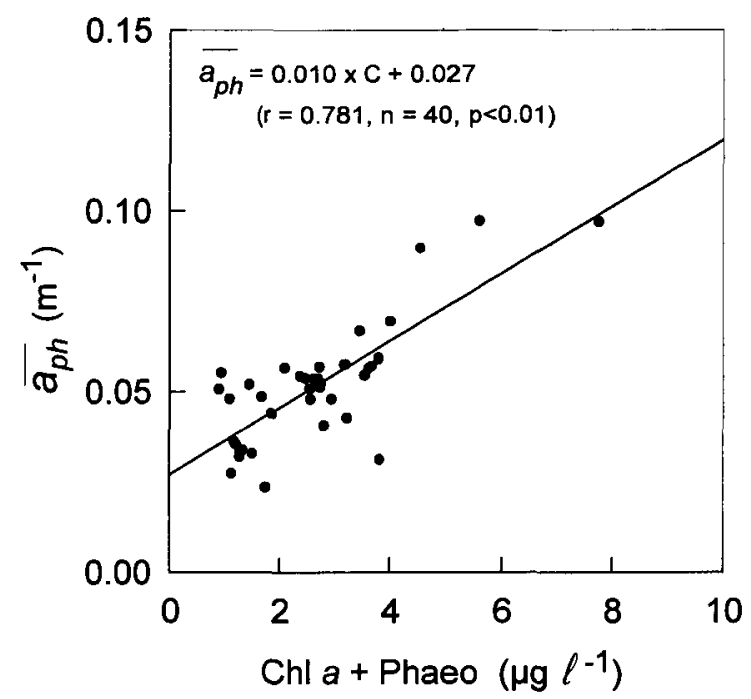

Fig. 15. Variation in the absorption coefficient averaged over PAR, $\bar{a}_{\mathrm{ph}}$, and the concentrations of chlorophyll $a$ plus phaeo-pigment (Chl-a+Phaeo). All data obtained in September 1994 and 1995 are plotted.

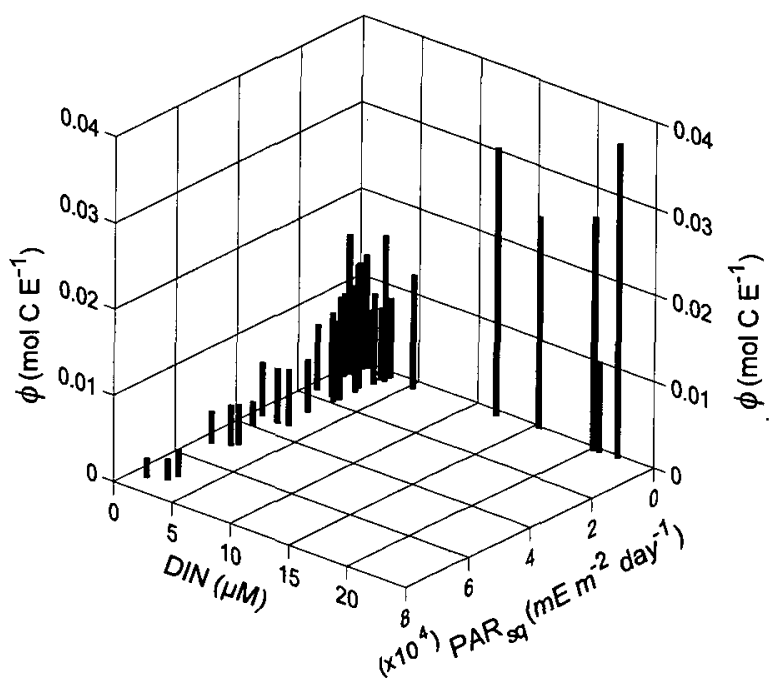

Fig. 16. The relation between dissolved inorganic nitrogen (DIN), $\mathrm{PAR}_{\mathrm{s} q}$, and $\phi$. 


\section{DISCUSSION}

The results presented here show that the spectral irradiance in deep water is dominated by green light (Fig. 5) in agreement with TSUDA and NAKANISHI $(1989,1990)$. It appears that water in the northern basin of Lake Biwa has suspended particles and yellow substances in concentrations similar to the coastal ocean. It is interesting that the value of $\phi$ decreased with increasing $\bar{a}_{p h}^{*}$ and was small while $\mathrm{PAR}_{\mathrm{sq}}$ was large, but increased with decreasing $\mathrm{PAR}_{\mathrm{sq}}$. This result indicates that phytoplankton under weak light condition are capable of efficient photosynthesis by increasing the quantum yield, in spite of the decrease in the efficiency of light absorption (Fig. 9). The increasing tendency of $\phi$ to increase/decrease with depth, including its maximum coinciding with the metalimnetic FL or pigment maximum, should be in part due to the dominance of APP (Fig. 12), a species capable of efficient utilization of weak light in a layer dominated by green absorption. Such features exemplify the adaptation of APP to the weak light dominated by green light in the deep water. TsUDA and NAKANISHI (1992) similarly described such a feature in the northern basin of Lake Biwa while analyzing the effect of spectral variations in the underwater radiation energy on the efficiency of primary production.

The increase in $\phi$ with decreasing $\mathrm{PAR}_{\mathrm{Sq}}$ agrees with results from previous studies in the ocean (e.g., TYLER, 1975 ; MoREL, 1978 ; KISHINo et al., 1986, MitCheLl and KIEFER, 1988b) and of the lakes (e.g., DuBInSKY and BERMAN, 1981). That the value of $\phi$ was small in the near surface region under conditions of higher $\mathrm{PAR}_{\mathrm{sq}}$, indicates that photosynthesis under strong radiation is subject to photoinhibition. Because $\phi$ covaried with the ratio $a_{p h}$ $(565) / a_{p h}(675)$ (Fig. 11), the concentration of auxiliary pigments should play some role in the increase in the value of $\phi$, while $\bar{a}_{p h}^{*}$ decreased with decreasing PAR. This suggests that the higher absorption at $565 \mathrm{~nm}$, which is marked in deep water with weak light, contributes significantly to the process of photosynthesis. In other words, phycoerythrin efficiently transfers the absorbed light energy into chemical energy in the weak light environment of deep water. This may in part explain the dominance of Synechococcus sp., which contains the pigment zeaxanthin observed in both 1994 and 1995. This pigment, which prevents the inhibition of phytoplankton growth, increases in the presence of Synechococcus growing under strong radiation conditions, sometimes appears at grater concentrations than chlorophyll $a$ or phycoerythrin (KANA et al., 1988). Zeaxanthin also contributes to light absorption under strong radiation, which could then lower the quantum yield. This is analogous to the conclusion of BABIN et al. (1996) that the quantum yield of production could be small when phytoplankton contain pigments of no use for photosynthesis. Although chlorophyll $a$ is usually taken into account to evaluate the value of $\bar{a}_{p h}^{*}$, our present results suggest that the effects of other pigments cannot be neglected.

That the value of $\phi$ remained low under DIN limited conditions agrees with the laboratory study by Cleveland and PerRY (1987). Similarly, 
BABIN et al. (1996) described the dependence of $\phi$ on nitrogen-nutrient concentrations, concluding that the rate of photosynthesis depends on light intensity and the concentration of nutrients. That the value of $\phi$ could be increased when DIN is high, is advantageous for effective photosynthesis in deep water under with weak light conditions.

\section{CONCLUSIONS}

We have considered the quantum yield of photosynthesis, $\phi$ as a measure of in situ primary productivity. Its variation with underwater light distributions, spectral absorption by phytoplankton, and in situ nutrient concentrations were examined. As a result, the value of $\phi$ clearly depended on the in situ optical field and variations in the absorption spectra due to the composition of photosynthetic pigments in the phytoplankton. In other words, $\phi$ depends on the in situ light environment and species composition in addition to physiological conditions of phytoplankton species present. It was found that the nutrient concentration, DIN in particular, could affect the $\phi$ value.

Since the quantitative evaluation of $\phi$ is important for application of bio-optical processes to a method to estimate primary production (ChAMBERLIN and MARRA, 1992), similar values of $\phi$ should be obtained from measurements made under various environmental conditions. The variation of $a_{p h}$ and $\phi$ with time and depth (Fig. 13) may be natural because of the ability of phytoplankton to absorb light energy depends on the surrounding environment, such as spectral distributions of light, temperature, nutrients, and even static pressure which depends on depth (DUBINSKY, 1980). Underwater bio-optical properties could thus change depending on time and area in oceans and lakes. In this context, we conclude that bio-optical research should be conducted seasonally and at diverse locations such as in more turbid parts of this and other lakes (e.g., DUBINSKY and BERMAN, 1976) as well as in the coastal ocean (e.g., HoEFFNER and SATHYENDRANath, 1992).

\section{ACKNOWLEDGEMENTS}

This paper is dedicated to the memory of Professor Ryohei TsudA, who devoted his life to the study of hydrospheric bio-optical processes. Sincere thanks are due to Professor M. NAKANISHI for valuable discussion and comments on this research. Drs. J. Urabe and S. NAKANo also helped greatly this study. Without the assistance by students of both the Center for Ecological Research, Kyoto University and Faculty of Agriculture, Kinki University, this research could never be accomplished. We thank Professor D. EDGINGTON (Great Lakes Water Research Institute of University of Wisconsin) for useful discussion and comments, and correction of English of this manuscript. We are grateful to the anonymous referees and editors who patiently provided useful comments and discussion to improve the manuscript, which Professor Ryohei TsudA could not complete before his death. This work was supported in part by a Grant-in-Aid for Scientific Research 
06304048 from the Japanese Ministry of Education, Science and Culture. Research data were obtained by use of the valuable equipment of the Regional Environmental Monitoring System of Kinki University.

\section{REFERENCES}

Babin, M., A. Morel, H. Claustre, A. Bricaud, Z. Kolber and P. G. Falkowski (1996) : Nitrogen- and irradiance-dependent variations of maximum quantum yield of carbon fixation in eutrophic, mesotrophic and oligotrophic marine systems. Deep-Sea Res., $43: 1241-1272$.

BeNDSCHNEIDER, K. and R. T. RoBinson (1952): A new spectrophotometric method for determination of nitrite in sea water. J. Mar. Res., 11: 87-96.

Bidigare, R. R., R. C. SMith, K. S. Baker and J. Marra (1987) : Oceanic primary production estimates from measurements of spectral irradiance and pigment concentrations. Global Biogechem. Cycles, $1: 171-186$.

Bricaud, A., A. Morel, and L. Prieur (1981) : Absorption by dissolved organic matter of the sea (yellow substance) in the UV and visible domains. Limnol. Oceanogr., $26: 43-53$.

Bricaud, A. and D. Stramski (1990) : Spectral absorption coefficients of living phytoplankton and nonalgal biogenous matter: A comparison between the Peru upwelling area and the Sargasso Sea. Limnol. Oceanogr., $35: 562-582$.

ChAMBERLIN, S. and J. MARRA (1992) : Estimation of photosynthetic rate from measurements of natural fluorescence: analysis of the effects of light and temperature. Deep-Sea Res., $39: 1695-1706$.

Cleveland, J. S. and M. J. Perry (1987) : Quantum yield, relative specific absorption and fluorescence in nitrogen-limited Chaetoceros gracilis. Mar. Biol., 94 : 489-497.

Cleveland, J. S., M. J. Perry, D. A. Kiefer and M. C. Talbot (1989) : Maximal quantum yield of photosynthesis in the northwestern Sargasso Sea. J. Mar. Res., $47: 869-886$.

Dubinsky, Z. (1980) : Light utilization efficiency in natural phytoplankton communities. In Primary Productivity in the Sea, P. G. FALKowSKI (ed.) : 83-97. Plenum Press, New York.

Dubinsky, Z. and T. BERMAN (1976) : Light utilization efficiencies of phytoplankton in Lake Kinneret (Sea of Galilee). Limnol. Oceanogr., 21 : 226-230.

Dubinsky, Z. and T. BERMAN (1981) : Light utilization by phytoplankton in Lake Kinneret (Israel). Limnol. Oceanogr., $26: 660-670$.

Garver, S. A., D. A. Siegel and B. G. Mitchell (1994) : Variability in nearsurface particulate absorption spectra: What can a satellite ocean color image see? Limnol. Oceanogr., $39: 1349-1367$.

Gordon, H. R., D. K. Clark, J. W. Brown, O. B. Brown R. H. Evans and W. W. BRoEnKow (1983): Phytoplankton pigment concentrations in the Middle Atlantic Bight: comparison of ship determinations and CZCS estimates. Appl. Opt., $22: 20-36$.

HoepfFner, N. and S. Sathyendranath (1992) : Bio-optical characteristics of coastal waters : Absorption spectra of phytoplankton and pigment distribution of phytoplankton and pigment distribution in the western North Atlantic. Limnol. Oceanogr., 37 : 1660-1679. 
Kana, T. M., P. M. Gilber'T, R. Goericke and N. A. Welschmeyer (1988): Zeaxantin and $\beta$-carotene in Synechococcus WH7803 respond differently to irradiance. Limnol. Oceanogr., 33 : 1623-1627.

Kiefer, D. A. and B. G. Mitchell (1983) : A simple, steady-state description of phytoplankton growth based on absorption cross section and quantum efficiency. Limnol. Oceanogr., 28 : 770-776.

KIEFER, D. A. and J. B. Soohoo (1982) : Spectral absorption by marine particles of coastal waters of Baja California. Limnol. Oceanogr., 27 : 492-499.

KIRK, J. T. O. (1983) : Light and photosynthesis in aquatic ecosystems. Cambridge University Press, $401 \mathrm{p}$.

Kishino, M., N. OKami, M. TAKahashi, and S. Ichimura (1986) : Light utilization efficiency and quantum yield of phytoplankton in a thermally stratified sea. Limnol. Oceanogr., $31: 557-566$.

Kishino, M., M. Takahashi, N. OKami and S. Ichimura (1985) : Estimation of the spectral absorption coefficients of phytoplankton in the Sea. Bull. Mar. Sci., $37: 634-643$.

LORENZEN (1967) : Determination of chlorophyll and phaeo-pigments : spectrophotometric equations. Limnol. Oceanogr., $12: 343-346$.

Mitchell, B. G. and D. A. KiEfer (1988a) : Chlorophyll $a$ specific absorption and fluorescence excitation spectra for light-limited phytoplankton. Deep-Sea Res., 35 : 639-663.

Mttchell, B. G. and D. A. KIEFER (1988b) : Variability in pigment specific particulate fluorescence and absorption spectra in the northeastern Pacific Ocean. Deep-Sea Res., 35 : 665-689.

MoRel, A. (1978) : Available, usable, and stored radiant energy in relation to marine photosynthesis. Deep-Sea Res., 25 : 673-688.

Morel, A. and A. BricaUd (1981) : Theoretical results concerning light absorption in a discrete medium, and application to specific absorption of phytoplankton. Deep-Sea Res., $28: 1375-1393$.

MurPhy, L. and J. P. RILEY (1962) : A modified single solution method for the determination of phosphate in natural waters. Anal. Chem. Acta, $27: 31-36$.

Roessler, C. S., M. J. Perry and K. L. Carder (1989) : Modeling in situ phytoplankton absorption from total absorption spectra in productive inland marine waters. Limnol. Oceanogr., $34: 1510-1523$.

SAGI, T. (1966) : Determination of ammonia in sea water by the indophenol method and its application to the coastal and off-shore waters. Oceanogr. Mag., $18: 43-51$.

Satake, K., Y. Saijo and H. Tominaga (1972) : Determination of small quantities of carbon dioxide in natural waters. Jpn. J. Limnol., 33:16-20.

Shibata, K. (1958) : Spectrophotometry of intact biological materials. Absolute and relative measurements of their transmission, reflection and absorption spectra. J. Biochem., $45: 599-623$.

SMITH, R. C. and K. S. BAKER (1981) : Optical properties of the clearest natural waters (200-800 nm). Appl. Optics, $20: 177-184$.

SNedeCOR, G. W. and W. G. Cochran (1967) : Statistical Methods, 6th ed. The Iowa State Univ. Press, $593 \mathrm{p}$.

Steemann Nielsen, E. (1952) : The use of radio-active carbon $\left({ }^{14} \mathrm{C}\right)$ for measuring organic production in the sea. J. Cons. Int. Explor. Mer, 18 : 117-140. 
TANs, P. P., I. Y. FunG and T. TAKahashi (1990) : Observational constrains on the global atmospheric $\mathrm{CO}_{2}$ Budget. Science, 247 : 1431-1438.

TsudA, R. (1980) : Measurements of underwater spectral irradiance in Lake Biwa. Jpn. J. Limnol., $41: 57-67$.

TsudA, R. and M. NAKANISHI (1989) : Optical properties and their relation to light utilization by phytoplankton in the stratified period in the north basin of Lake Biwa. Arch. Hydrobiol., 116 : 235-244.

TsudA, R. and M. NAKANISHI (1990) : Spectral distribution characteristics in downwelling irradiance and optical properties within the euphotic layer in the north basin of Lake Biwa. Arch. Hydrobiol., 119 : 279-292.

Tsuda, R., and M. Nakanishi (1992) : Light utilization by phytoplankton in the north basin of Lake Biwa. Arch. Hydrobiol., 125 : 97-107.

TyleR, J. E. (1975) : The in situ quantum efficiency of natural phytoplankton populations. Limnol. Oceanogr., $20: 976^{-980 .}$

WhitTAKeR, R. H. and G. E. LiKens (1973): The primary production of the biosphere. Human Ecol., 1 : 299-369.

Wood, E. D., F. A. J. Armstrong and F. A. Richards (1967) : Determination of nitrate in sea water by cadmium-copper reduction to nitrite. J. mar. biol. Ass. U. K., $47: 23-31$.

Yuji TANaKa : Department of Ocean Sciences, Tokyo University of Fisheries, 45-7 Konan, Minato-ku, Tokyo 108-8477 (田中祐志：干 108-8477 東京都港 区港南 4-5-7 東京水産大学海洋環境学科)

Ryohei TsudA : Department of Fisheries, Kinki University, 3327 Nakamachi, Nara 631-8505（津田良平：干 631-8505 奈良市中町 3327 近畿大学農学部 水産学科)

Minako Mizutani : Department of Fisheries, Kinki University, 3327 Nakamachi, Nara 631-8505（水谷美直子：T 631-8505 奈良市中町 3327 近畿大学農学 部水産学科)

Osamu Mitamura : Limnological Laboratory, School of Environmental Science, The University of Shiga Prefecture, 3165 Hassaka, Hikone, Shiga 522-0057 (三田村緒佐武：干 522-0057 彦根市八坂町 3165 滋賀県立大学 環境科学部 湖沼環境実験施設)

(Received : 31 July 1999 ; Accepted : 8 December 1999) 


\title{
琵琶湖北湖の水温成層期における光合成量子収量と 植物プランクトンの光吸収スペクトル
}

\author{
田中祐志・津田良平・水谷美直子・三田村緒佐武
}

摘要

光合成の量子収量を決定する要因を理解するために, 琵琶湖北湖において水温成層期に 野外調查が行われた。調查は 1994 年と 1995 年の 9 月に反復され, 光エネルギーの分光分 布，植物プランクトンによる光吸収および光合成速度が，水温，クロロフィル営光強度， 光束透過率，栄養塩濃度などの鉛直分布とともに観測された。光合成有効放射 (PAR) 波 長帯内の平均光吸収係数は, クロロフィル $a$ とフェオ色素との合計の濃度が高いほど大き かった。光合成の量子収量 $(\phi)$ は, 放射強度が小さいほど高かった。この傾向は, PAR が $10 \mathrm{E} \mathrm{m}^{-2} \mathrm{day}^{-1}$ を越える場合に顕著であった。фはまた, 植物プランクトンの単位色素濃 度あたりの光吸収係数(比吸収係数)が低いほど大きかった。さらに, 弱光下において溶存 無機態窒素が高濃度のとき， $\phi$ が大きいことが観察された。これらのことは, 弱光である が栄養塩濃度が高い有光層下部において, 植物プランクトンが光エネルギーを光合成に効 率よく利用していたことを示唆している。 